\title{
Imperata yellow mottle virus: An Emerging Threat to Maize, Sorghum and Pearl Millet in Burkina Faso
}

\section{Moustapha Koala1,2*, Valentin Stanislas Edgar Traoré1, Drissa Sérémé1, Bouma James Neya1, Christophe Brugidou1,3, Nicolas Barro' ${ }^{2}$, Oumar Traoré1}

${ }^{1}$ Laboratoire Mixte Internationale (LMI) Patho-Bios, Institut de l'Environnement et de Recherches Agricoles (INERA), Ouagadougou, Burkina Faso

${ }^{2}$ Universite Ouaga I Professeur Joseph Ki-Zerbo, Ouagadougou, Burkina Faso

${ }^{3}$ UMR IPME (UM, IRD, CIRAD), Institut de Recherche pour le Développement, IRD, Montpellier, France

Email: *koalamoustapha@gmail.com

How to cite this paper: Koala, M., Traoré, V.S.E., Sérémé, D., Neya, B.J., Brugidou, C., Barro, N. and Traoré, O. (2017) Imperata yellow mottle virus. An Emerging Threat to Maize, Sorghum and Pearl Millet in Burkina Faso. Agricultural Sciences, 8, 397-408. https://doi.org/10.4236/as.2017.85030

Received: April 8, 2017

Accepted: May 23, 2017

Published: May 27, 2017

Copyright $\odot 2017$ by authors and Scientific Research Publishing Inc. This work is licensed under the Creative Commons Attribution International License (CC BY 4.0).

http://creativecommons.org/licenses/by/4.0/

(c) (i) Open Access

\begin{abstract}
Imperata yellow mottle caused by Imperata yellow mottle virus (IYMV) of the genus Sobemovirus was first characterized on Imperata cylindrica and Zea mays in Burkina Faso. The disease has been reported in several localities of the country but its ecology and epidemiology are poorly known. In particular, only I. cylindrica and maize have been reported within IYMV host range. The aim of this study was to investigate the experimental host range of the virus. Mechanical inoculation of a mixture of four IYMV isolates to 18 plant species, including four crops (maize, rice, sorghum and pearl millet) and 14 wild grasses showed clear mottle symptoms in maize, sorghum and pearl millet and two wild grass species (Setaria verticillata and Rottboellia exaltata). Symptom development was confirmed by Enzyme-linked immunosorbent assay and reverse transcription-polymerase chain reaction (RT-PCR). Infection of crop species by IYMV depended on cultivars tested. Therefore, proportions of positive cultivars were $16 / 36$ in maize, $4 / 10$ in sorghum and 4/9 in pearl millet, respectively. Studies on virus-host interactions using individual virus isolates showed two pathogenic patterns. Three out of the four isolates tested infected all plant species and cultivars. In contrast, the fourth IYMV isolate could infect only one maize cultivar. These results expand the previously known host range of IYMV from two to five species, indicating a narrow host range. Among the new characterized host species, sorghum and pearl millet are important cereal crops. Therefore, Imperata yellow motte disease is a potential threat for the cereal crop production and its ecology and epidemiology should be thoroughly investigated.
\end{abstract}




\section{Keywords}

IYMV, Sobemovirus, Host Range, Virus-Host Interactions

\section{Introduction}

Cogon grass (Imperata cylindrica), also known as kunai grass, blady grass, satintail, spear grass, sword grass or thatch grass, is a perennial grass species occurring worldwide in tropical and subtropical regions [1] [2] [3]. It is often considered as an invasive species and a serious wild weed which competes with crops such as cassava, maize, rice, sorghum, pearl millet for water and nutrients.

However, several beneficial uses of the plant have been reported. In particular, the leaves and the roots are commonly used in herbal medicine for the treatment of diseases and illnesses like snakebites, high blood pressure, and typhoid [4] [5] [6]. Diuretic and anti-cancer properties of $I$. cylindrica extracts were also reported [7] [8].

In the early 2000, a new viral disease was reported on I. cylindrica in Burkina Faso [9]. Disease symptoms consisted of yellow mottling of the leaves. The causal agent was subsequently characterized as a sobemovirus named Imperata yellow mottle virus, acronym IYMV [10]. The virus was readily transmitted by mechanical inoculation to susceptible hosts. IYMV host range is poorly known. Under natural conditions, IYMV was only found in I. cylindrica and maize (Zea mays) in different parts of the country. Only itch grass (Rottboellia exaltata) was reported within the artificial host range [10]. Possibly, other cereal crops grown along with maize in the same environments are affected by the virus. Moreover, like I. cyclindrica, the virus may be hosted by other wild species. Knowledge of crops species and wild plant species hosting IYMV is necessary for assessing the virus agronomical importance as well as devising adequate control measures based on epidemiological characteristics and resistant or tolerant crop varieties.

In this paper, we assessed the susceptibility of several maize varieties to IYMV and studied the artificial host range mainly among cereal crops and wild graminaceous plant species. Knowledge of the artificial host range of the virus would ease the investigations on the natural host range.

\section{Methods}

\subsection{Sources of Inoculum}

Leaf samples of $I$. cylindrica showing typical yellow mottle symptoms were collected in different localities in Burkina Faso (Figure 1). Infection by IYMV was confirmed in leaf extracts by ELISA and RT-PCR tests against healthy leaves used as negative controls. Virus isolates included Bf4, Bz16, Lo9 and T2 and originated from the following respective localities: Banfora (lat: 10.680277; lon: -4.793233), Banzon (lat: 11.318989, lon: -4.8044071), Lomouroudougou (lat: 10.693140, lon : (-4.794290) and Tondogosso (lat: 11.41090, lon: -3.0092). 


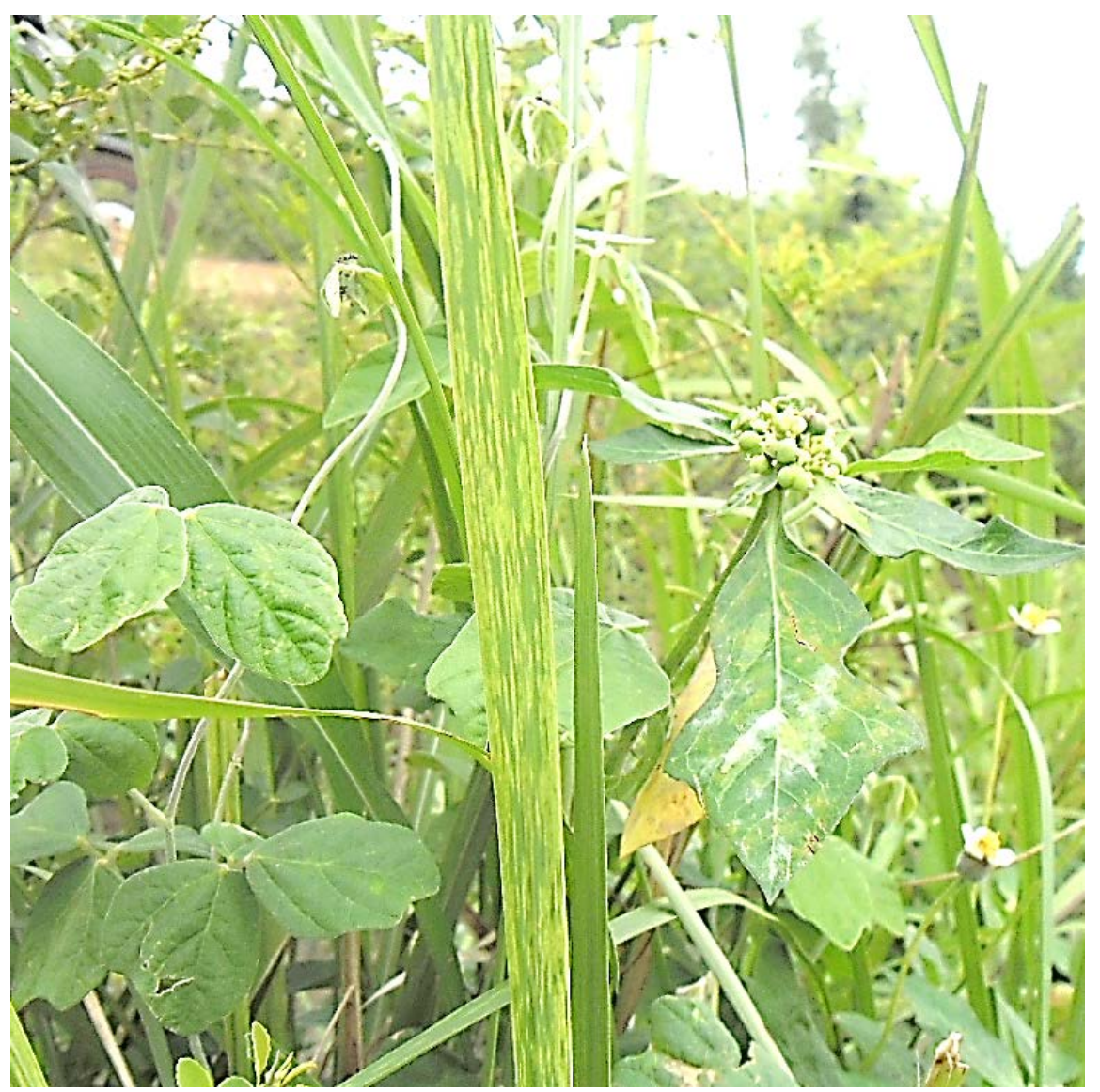

Figure 1. Leaf of Imperata cylindrica with yellow mottle symptoms.

\subsection{Mechanical Inoculation}

Infected leaves from each isolate were macerated at a ratio of $1 / 10(\mathrm{~g} / \mathrm{ml})$ in 0.01 M phosphate buffer, pH 7.0 and dusted with 600 mesh carborundum. Leaf extracts were rubbed onto the leaves of maize cv. FBC6 seedlings a week after sowing in order to propagate the virus isolates. Infected leaves from each propagated virus isolate were collected two weeks post-inoculation and pooled at equal weights to prepare a composite inoculum for host range studies. Virus isolates were also used individually for additional characterization of host species. Inoculated plants were maintained in an insect-proof greenhouse under normal ambient condition $\left(28^{\circ} \mathrm{C}\right.$ to $\left.30^{\circ} \mathrm{C}\right)$ for symptom development.

\subsection{Host Range Determination}

Four cereal crops, namely maize (Zea mays), sorghum (Sorghum bicolor), pearl millet (Pennisetum glaucum) and rice (Oryza sativa and O. glaberrima) were used for host range studies. A total of 84 cultivars of these crops originating from several research institutions were tested (Table 1). Plant seeds were sown in separate plots according to the species. Virus inoculum was prepared from four IYMV isolates including Bf4, Bz16, Lo9 and T2 as indicated above and was applied to 10 seedlings/plant species. Inoculation was done on the first fully expanded leaf, generally 3 to 5 days after emergence. Fifteen wild grass species in- 
Table 1. Cereal crops and cultivars tested in the IYMV host range study.

\begin{tabular}{|c|c|c|c|}
\hline \multirow[t]{2}{*}{ Plant species } & \multicolumn{3}{|c|}{ Cultivars } \\
\hline & Names & number & Origin $^{a}$ \\
\hline \multirow[t]{2}{*}{ Oryza glaberrima } & CG14, TOG5307, TOG5674, TOG5681 & 4 & $\begin{array}{l}\text { IITA/Africa Rice } \\
\text { (Nigeria/Benin) }\end{array}$ \\
\hline & TOG5428, TOG7291 & 2 & IITA (Nigeria) \\
\hline \multirow[t]{6}{*}{ Oryza sativa } & Azucena & 1 & IRRI (Philippine) \\
\hline & BG 90-2 & 1 & IITA (Nigeria) \\
\hline & Bekarosaka & 1 & Madagascar \\
\hline & IR64 & 1 & IRRI (Philippine) \\
\hline & AC 104589, TNG67 & 2 & IRD (Montpellier) \\
\hline & $\begin{array}{c}\text { Digang, Dissi, FKR19, FKR28, } \\
\text { Malogouè, Nipponbare, TS2, } \\
\text { Gigante, FKR56N, FKR62N, FKR60N }\end{array}$ & 11 & INERA (Burkina Faso) \\
\hline Sorghum bicolor & $\begin{array}{l}\text { Fambe, Gnofing, gringan, ICSV1049, } \\
\text { Malibar, Kapelga, Kouria, SO7, S11, S14 }\end{array}$ & 10 & INERA (Burkina Faso) \\
\hline Pennisetum glaucum & $\begin{array}{l}\text { MS CIV A, MS CIV NA, SOSAT-C88, } \\
\text { MISARI 1, MISARI 2, IKPM1, IKPM5, } \\
\text { IKMV 8202, IBMV8402 }\end{array}$ & 9 & INERA (Burkina Faso) \\
\hline \multirow[t]{14}{*}{ Zea mays } & $\begin{array}{l}\text { CML52, CML69, CML103, CML228, } \\
\text { CML247, CML277, CML333,CML322 }\end{array}$ & 8 & CIMMYT (Mexico) \\
\hline & TZi8 & 1 & IITA (Nigeria) \\
\hline & $\begin{array}{c}\text { Bondofa, Barka, Espoir, FBC6, KEB, KEJ, } \\
\text { Komsaya, KPB, KPJ, Massongo, Wari }\end{array}$ & 11 & INERA (Burkina Faso) \\
\hline & B73, B97 & 2 & Iowa (USA) \\
\hline & HP301 & 1 & Indiana (USA) \\
\hline & $\mathrm{II} 14 \mathrm{H}$ & 1 & Illinois (USA) \\
\hline & Ki3, Ki11 & 2 & Thailand \\
\hline & Ky 21 & 1 & Kentucky (USA) \\
\hline & M37W, M162W & 2 & Natal (South Africa) \\
\hline & Ms71 & 1 & Michigan (USA) \\
\hline & Mo18W & 1 & Missouri (USA) \\
\hline & NC350, NC358 & 2 & North Carolina (USA) \\
\hline & Oh7B, OH43 & 2 & Ohio (USA) \\
\hline & Tx303 & 1 & Texas (USA) \\
\hline
\end{tabular}

aCIMMYT: International Maize and Wheat Improvement Centre, IITA: International Institute of Tropical Agriculture, INERA: Institute of Environment and Agricultural Research

cluding I. cylindrica were also tested. Plantlets obtained from seeds were mechanically inoculated 30 days after sowing generally. Inoculated plants were maintained in an insect-proof greenhouse for up to 45 days to monitor symptom development. In order to confirm IYMV presence or absence in inoculated plants, leaf samples were tested by serology and RT-PCR tests.

\subsection{Serological Detection Tests}

IYMV were diagnosed in plant extracts using triple-antibody sandwich enzyme-linked immunosorbent assay as previously described [11]. In brief, the 
procedure was the following: Immunoplates (Nunc) were coated for $2 \mathrm{~h}$ with IgY polyclonal antibody as primary antibody in $0.5 \mathrm{M}$ carbonate buffer, $\mathrm{pH}$ 9.6. Leaf samples were extracted in phosphate buffered saline $\mathrm{pH} 7.4$ containing $0.05 \%$ Tween $20 \%$ and $0.1 \%$ skimmed milk. Leaf samples were incubated in duplicate overnight at $4^{\circ} \mathrm{C}$. Then, rabbit anti-IYMV polyclonal antibody was added as secondary antibody, followed by incubation of anti-rabbit alkaline phosphatase conjugate. Para-nitrophenolphosphate substrate was added at $1 \mathrm{mg} / \mathrm{ml}$ in $9.7 \%$ diethanolamine, $\mathrm{pH}$ 9.8. Plates were incubated for $1 \mathrm{~h}$ at $37^{\circ} \mathrm{C}$ and absorbance values were recorded at $405 \mathrm{~nm}$ using a Metertech $\Sigma 960$ multiskan microplate reader. Both inoculated and non-inoculated plant samples were analyzed. XLSTAT, statistical software for excel was used for data analysis. Samples were considered positive if their corresponding absorbance values were greater than the mean value for healthy controls plus three times the standard deviation.

\subsection{RNA Extraction and RT-PCR Tests}

Total RNA was extracted from plant leaves using RNeasy plant mini-kit (Qiagen), according to the manufacturer's instructions. RNA was also extracted from healthy leaves to be used as negative controls. One microgram of each RNA preparation was reverse-transcribed and resulting cDNA was amplified using a set primers specific to IYMV.

For reverse-transcription (RT), $1 \mu \mathrm{g}(\sim 4 \mu \mathrm{l})$ of total RNA was mixed with $1 \mu \mathrm{l}$ of $10 \mu \mathrm{M}$ reverse primer IYMV-R4438-4454 (5'CGCCGCGACAACAGAGG3'). The reaction was heated for $10 \mathrm{~min}$ at $70^{\circ} \mathrm{C}$ and immediately chilled on ice. Then the RT mix was added and the reaction ( $25 \mu \mathrm{l}$ total volume) was incubated for $1 \mathrm{~h}$ at $42^{\circ} \mathrm{C}$. The RT mix was composed of $5 \mu \mathrm{l}$ of $5 \times \mathrm{RT}$ buffer, $0.5 \mu \mathrm{l}$ of $25 \mathrm{U}$ RNase inhibitor, $1 \mu \mathrm{l}$ of $200 \mathrm{U}$ of M-MLV-reverse transcriptase, $1 \mu \mathrm{l}$ of $10 \mathrm{mM}$ dNTPs and sterile water.

IYMV coat protein coding region was amplified using primers IYMV F3483-3502 (5'AAACACAAGCAGGCAATGGG3') and IYMV_R4385-4404 (5' GCCGGACTCTCCTACCTTTG3') designed based on IYMV sequence accession number NC_011536. The PCR reaction mixture contained $2 \mu \mathrm{l}$ of first strand cDNA, $5 \mu \mathrm{L}$ of 10x PCR buffer, $1 \mu \mathrm{l}$ of $10 \mathrm{mM}$ dNTPs, forward and reverse primers $\left(1 \mu \mathrm{l}\right.$ of each) and $0.08 \mu \mathrm{L}$ of Go taq ${ }^{\circledR}$ Flexi DNA Polymerase in $20 \mu \mathrm{l}$ reaction volume. The thermo-cycling conditions were as follows : $5 \mathrm{~min}$ at $94^{\circ} \mathrm{C}(1$ cycle), $94^{\circ} \mathrm{C}$ for $30 \mathrm{~s}, 55^{\circ} \mathrm{C}$ for $30 \mathrm{~s}$ and $72^{\circ} \mathrm{C}$ for $1 \mathrm{~min}$ ( $35 \mathrm{cycles}$ ), and a final extension at $72^{\circ} \mathrm{C}$ for $7 \mathrm{~min}$. A reaction containing no cDNA template was included in all PCR tests as a blank control.

\section{Results}

\subsection{Symptom Development}

Of the 18 plants species tested, only three crops and two wild grasses developed symptoms in addition to I. cylindrica used as positive control (Figure 2). Susceptible crop species included maize, sorghum and pearl millet. No symptom appeared on inoculated rice plants whatever the species or the cultivar. In maize 




Figure 2. Leaves of inoculated plants species showing symptoms at two different periods (in days post-inoculation dpi). Healthy leaves are shown on the left for each species.

and pearl millet, symptoms first developed as broken chlorotic lines along the nerves, clearly visible 10-12 days post-inoculation (dpi). Later on, typical mottle symptoms developed at $20 \mathrm{dpi}$. In sorghum, faint mosaic symptoms clearly appeared at $17 \mathrm{dpi}$ and turned to yellow mosaic symptoms at $30 \mathrm{dpi}$.

In wild grasses, $R$. exaltata and $I$. cylindrica developed symptoms similar to those in maize at $12-14 \mathrm{dpi}$. However, as infection progressed, diseased plants showed more severe mottle symptoms with a bright yellow discoloration. In $S$. verticillata, symptoms first developed as chlorotic dots which evolved gradually into severe yellow mottle symptoms.

\subsection{Virus Detection by ELISA and RT-PCR}

IYMV presence was ascertained in leave extracts from all symptomatic plants. Corresponding absorbance values at $405 \mathrm{~nm}$ (A405 nm) ranged between 0.736 in sorghum cv. ICSV1049 and 1.578 in maize cv. Ky21 (Table 2). In any case, A405 $\mathrm{nm}$ values were far greater than the threshold values which did not exceed 0.080, clearly indicating IYMV detection. RT-PCR tests indicated the amplification of a 995 bp fragment from all ELISA positive samples (Figure 3). Moreover, back-inoculation of leaf extracts from symptomatic plants to $I$. cylindrica led to the development of typical yellow mottle symptoms. By contrast, asymptomatic leaf samples were all negative in either ELISA or RT-PCR tests. In addition, no symptom developed when leaf extracts were back-inoculated in maize cv. FBC6 or I. cylindrica.

\subsection{Reactions of Plant Species to Individual Virus Isolates}

Virus-host interactions between individual virus isolates and plant species which reacted positively to virus infection are presented in Table 3. Two types of virus-host interactions were observed. The first type was characterized by the ability of virus isolates BF4, BZ16 and Lo9 to infect all crop species including their 


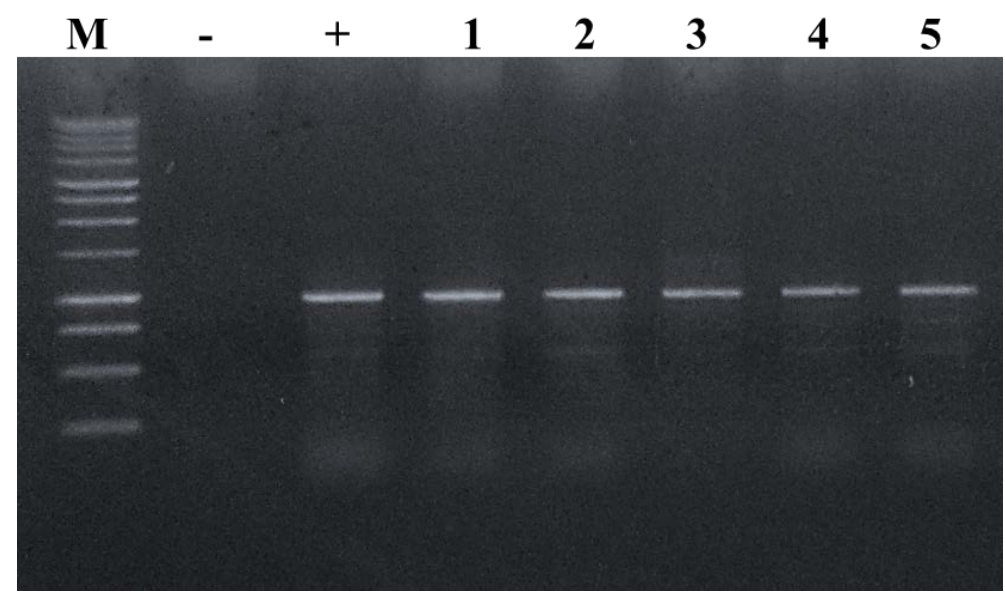

Figure 3. Agarose gel analysis of Reverse-Transcription Polymerase Chain Reaction (RT-PCR) assays for IYMV detection. M: $1 \mathrm{~kb}$ DNA ladder (PROMEGA); (-): sample from a healthy Imperata cylindrica plant used as negative control; (+) Sample from an infected Imperata cylindrica plant used in as positive control; (1): sample from zea mays; (2) sample from Sorghum bicolor, (3) sample from Pennisetum glacumt; (4) sample from Setaria verticillata and (5) sample from Rottboellia exaltata.

Table 2. Plant reaction to mechanical inoculation of IYMV in the host range study.

\begin{tabular}{|c|c|c|c|c|c|}
\hline Species, cultivar & Infected/tested ${ }^{a}$ & $\mathrm{Dpi}^{\mathrm{b}}$ & ELISA $^{c}$ & \multicolumn{2}{|c|}{ PCR $^{\mathrm{d}}$ Back-inoculation } \\
\hline \multicolumn{6}{|l|}{ Zea mays } \\
\hline Bondofa & $0 / 10$ & - & $0.033 \pm 0.001$ & - & - \\
\hline Barka & $0 / 10$ & - & $0.041 \pm 0.004$ & - & - \\
\hline Espoir & $0 / 10$ & - & $0.028 \pm 0.013$ & - & - \\
\hline FBC6 & $10 / 10$ & $12 \pm 2$ & $1.535 \pm 0.180$ & + & + \\
\hline B73 & $10 / 10$ & $14 \pm 2$ & $1.263 \pm 0.192$ & + & + \\
\hline B97 & $0 / 10$ & - & $0.013 \pm 0.004$ & & - \\
\hline CML52 & $0 / 10$ & - & $0.024 \pm 0.008$ & - & - \\
\hline CML69 & $0 / 10$ & - & $0.039 \pm 0.004$ & - & - \\
\hline CML103 & $0 / 10$ & - & $0.023 \pm 0.004$ & - & - \\
\hline CML228 & $0 / 10$ & - & $0.043 \pm 0.007$ & - & - \\
\hline CML247 & $0 / 10$ & - & $0.023 \pm 0.011$ & - & - \\
\hline CML277 & $0 / 10$ & - & $0.053 \pm 0.018$ & - & - \\
\hline CML333 & $0 / 10$ & - & $0.056 \pm 0.004$ & - & - \\
\hline CML322 & $0 / 10$ & - & $0.019 \pm 0.004$ & - & - \\
\hline FBMS1 & $06 / 10$ & $13 \pm 1$ & $1.182 \pm 0.025$ & + & + \\
\hline Massayomba $\mathrm{C} 1$ & $07 / 10$ & $13 \pm 2$ & $1.304 \pm 0.372$ & + & + \\
\hline FBPC2 & $08 / 10$ & $11 \pm 1$ & $1.445 \pm 0.183$ & + & + \\
\hline FBPC1 & $07 / 10$ & $11 \pm 0$ & $1.478 \pm 0.361$ & + & + \\
\hline HP301 & $0 / 10$ & - & $0.056 \pm 0.004$ & - & - \\
\hline $\mathrm{II} 14 \mathrm{H}$ & $0 / 10$ & - & $0.019 \pm 0.004$ & - & - \\
\hline
\end{tabular}




\section{Continued}

\begin{tabular}{|c|c|c|c|c|c|}
\hline Jaune de Fô & $09 / 10$ & $12 \pm 3$ & $1.343 \pm 0.242$ & + & + \\
\hline KEB & $07 / 10$ & $13 \pm 2$ & $1.353 \pm 0.173$ & + & + \\
\hline KEJ & $0 / 10$ & - & - & - & - \\
\hline Komsaya & $0 / 10$ & - & $0.023 \pm 0.004$ & - & - \\
\hline КРB & $09 / 10$ & $12 \pm 3$ & $1.067 \pm 0.098$ & + & + \\
\hline KPJ & $10 / 10$ & $12 \pm 0$ & $1.228 \pm 0.546$ & + & + \\
\hline Ky21 & $10 / 10$ & $17 \pm 3$ & $1.578 \pm 0.378$ & + & + \\
\hline KiII & $0 / 10$ & - & $0.013 \pm 0.004$ & - & - \\
\hline $\mathrm{Ki} 3$ & $08 / 10$ & $14 \pm 2$ & $1.351 \pm 0.090$ & + & + \\
\hline Massongo & $08 / 10$ & $13 \pm 3$ & $1.564 \pm 0.272$ & + & + \\
\hline M162W & $0 / 10$ & - & $0.015 \pm 0.002$ & & - \\
\hline M37W & $0 / 10$ & - & $0.050 \pm 0.028$ & & - \\
\hline Ms71 & $0 / 10$ & - & $0.024 \pm 0.008$ & & - \\
\hline Mo18W & $0 / 10$ & - & $0.034 \pm 0.005$ & & - \\
\hline NC350 & $0 / 10$ & - & $0.033 \pm 0.000$ & & - \\
\hline NC358 & $0 / 10$ & - & $0.031 \pm 0.011$ & & - \\
\hline Oh7B & $0 / 10$ & - & $0.019 \pm 0.004$ & - & - \\
\hline $\mathrm{OH} 43$ & $0 / 10$ & - & $0.013 \pm 0.004$ & - & - \\
\hline Sweet corn & $10 / 10$ & $16 \pm 1$ & $1.167 \pm 0.104$ & + & + \\
\hline SR 21 & $08 / 10$ & $16 \pm 4$ & $1.306 \pm 0.066$ & + & + \\
\hline $\mathrm{Tx} 303$ & $0 / 10$ & - & $0.050 \pm 0.028$ & - & - \\
\hline TZi8 & $0 / 10$ & - & $0.034 \pm 0.005$ & - & - \\
\hline Wari & $10 / 10$ & $15 \pm 1$ & $1.456 \pm 0.255$ & + & + \\
\hline \multicolumn{6}{|c|}{ Sorghum bicolor } \\
\hline ICSV1049 & $08 / 10$ & $24 \pm 7$ & $0.736 \pm 0.430$ & + & + \\
\hline Sariasso 7 & $10 / 10$ & $20 \pm 1$ & $1.033 \pm 0.124$ & + & + \\
\hline Gnofing & $10 / 10$ & $17 \pm 2$ & $1.038 \pm 0.113$ & + & + \\
\hline Sariasso 14 & $10 / 10$ & $20 \pm 2$ & $1.104 \pm 0.067$ & + & + \\
\hline Fambe & $0 / 10$ & - & $0.013 \pm 0.004$ & - & - \\
\hline gringan & $0 / 10$ & - & $0.024 \pm 0.008$ & - & - \\
\hline Malibar & $0 / 10$ & - & $0.039 \pm 0.004$ & - & - \\
\hline Kapelga & $0 / 10$ & - & $0.023 \pm 0.004$ & - & - \\
\hline Kouria & $0 / 10$ & - & $0.043 \pm 0.007$ & - & - \\
\hline S11 & $0 / 10$ & - & $0.031 \pm 0.011$ & - & - \\
\hline \multicolumn{6}{|c|}{ Pennisetum glaucum } \\
\hline IKMV 8202 & $10 / 10$ & $16 \pm 2$ & $1.182 \pm 0.026$ & + & + \\
\hline MS CIV A & $08 / 10$ & $19 \pm 1$ & $1.298 \pm 0.309$ & + & + \\
\hline IBMV8402 & $09 / 10$ & $20 \pm 1$ & $1.209 \pm 0.471$ & + & + \\
\hline
\end{tabular}




\section{Continued}

\begin{tabular}{|c|c|c|c|c|c|}
\hline MISARI 1 & $10 / 10$ & $18 \pm 2$ & $1.304 \pm 0.372$ & + & + \\
\hline MISARI 2 & $0 / 10$ & - & $0.012 \pm 0.002$ & - & - \\
\hline IKPM1 & $0 / 10$ & - & $0.045 \pm 0.028$ & - & - \\
\hline IKPM5 & $0 / 10$ & - & $0.035 \pm 0.039$ & & - \\
\hline MS CIV NA & $0 / 10$ & - & $0.031 \pm 0.017$ & - & - \\
\hline SOSAT-C88 & $0 / 10$ & - & $0.035 \pm 0.030$ & - & - \\
\hline \multicolumn{6}{|c|}{ Wild grass species } \\
\hline Acroceras zizaniodes & $0 / 10$ & - & $0.055 \pm 0.01$ & & - \\
\hline Brachiaria xantholeuca & $0 / 10$ & - & $0.035 \pm 0.006$ & & - \\
\hline Setarira barbata & $0 / 10$ & - & $0.040 \pm 0.003$ & & - \\
\hline Setaria pallide-fusca & $0 / 10$ & - & $0.030 \pm 0.002$ & - & - \\
\hline Setaria verticillata & $10 / 10$ & $14 \pm 2$ & $1.314 \pm 0.236$ & + & + \\
\hline Dactyloctenium aegyptium & $0 / 10$ & - & $0.025 \pm 0.003$ & & - \\
\hline Chloris Barbata & $0 / 10$ & - & $0.039 \pm 0.004$ & - & - \\
\hline Cynodon dactylon & $0 / 10$ & - & $0.023 \pm 0.004$ & - & - \\
\hline Cyperus rotondus & $0 / 10$ & - & $0.043 \pm 0.007$ & - & - \\
\hline Panicum maximun & $0 / 10$ & - & $0.014 \pm 0.002$ & - & - \\
\hline Paspalum dilatatum & $0 / 10$ & - & $0.032 \pm 0.026$ & - & - \\
\hline Pennisetum pedicellatum & $0 / 10$ & - & $0.042 \pm 0.008$ & & - \\
\hline Eleusine indica & $0 / 10$ & - & $0.060 \pm 0.010$ & - & - \\
\hline Rottboellia exaltata & $10 / 10$ & $16 \pm 4$ & $1.416 \pm 0.107$ & + & + \\
\hline Imperata cylindrica & $10 / 10$ & $17 \pm 3$ & $1.088 \pm 0.002$ & + & + \\
\hline Brachiaria xantholeuca & $10 / 10$ & $15 \pm 2$ & $1.056 \pm 0.005$ & + & + \\
\hline
\end{tabular}

${ }^{a}$ Number of symptomatic plants/total number of plants tested. ${ }^{b}$ Time for symptom development expressed in days post inoculation (dpi) \pm standard deviation). ${ }^{\circ}$ Mean Absorbance values at $405 \mathrm{~nm} \pm$ standard deviation obtained in ELISA tests. ${ }^{\mathrm{d}}$ Polymerase chain reaction (PCR): (+) for positive reaction, $(-)$ for negative reaction. ${ }^{e}$ Back-inoculation: (+) for presence of symptoms, $(-)$ for absence of symptoms

corresponding cultivars as well as all wild host species. Therefore, plant infection using these isolates was similar to that produced by inoculation of the composite virus isolate. The second type of virus-host interaction involved virus isolate T2 which on the one hand infected all wild host species. On the other hand, only maize cultivar FBC6 was infected. Inoculated plants from all other maize cultivars and crop species remained symptomless and no virus could be detected in leaves extracts by ELISA or RT-PCR.

\section{Discussion}

In this study, the experimental host range of IYMV was studied among cereal crops and wild grass species. Crop species included maize, sorghum, pearl millet and rice which are the major cereal crops grown in Africa. IYMV successfully infected maize and the wild grass species $R$. exaltata, which was consistent with 
Table 3. Reactions of selected plant species to individual virus isolates.

\begin{tabular}{|c|c|c|c|c|c|}
\hline \multirow[t]{2}{*}{ Species } & \multirow[t]{2}{*}{ Cultivar } & \multicolumn{4}{|c|}{ Virus isolates } \\
\hline & & $\mathrm{T} 2$ & BF4 & BZ16 & Lo9 \\
\hline Sorghum bicolor & Gnofing & - & + & + & + \\
\hline Sorghum bicolor & ICSV1049 & - & + & + & + \\
\hline Sorghum bicolor & Sariaso 7 & - & + & + & + \\
\hline Sorghum bicolor & Sariaso 14 & - & + & + & + \\
\hline Pennisetum glaucum & MS CIV A & - & + & + & + \\
\hline Pennisetum glaucum & IKMV 8202 & - & + & + & + \\
\hline Pennisetum glaucum & MISARI 1 & - & + & + & + \\
\hline Pennisetum glaucum & IBMV8402 & - & + & + & + \\
\hline Zea mays & FBC6 & + & + & + & + \\
\hline Zea mays & B73 & - & + & + & + \\
\hline Zea mays & KEB & - & + & + & + \\
\hline Zea mays & КРB & - & + & + & + \\
\hline Zea mays & KPJ & - & + & + & + \\
\hline Zea mays & Ку21 & - & + & + & + \\
\hline Zea mays & $\mathrm{Ki} 3$ & - & + & + & + \\
\hline Zea mays & Massongo & - & + & + & + \\
\hline Zea mays & Wari & - & + & + & + \\
\hline Setaria verticillata & & + & + & + & + \\
\hline Imperata cylindrica & & + & + & + & + \\
\hline Rottboellia exaltata & & + & + & + & + \\
\hline
\end{tabular}

Plants' reactions to inoculation: (+) for presence of symptoms, (-) for absence of symptoms.

earlier studies [9] [10]. Additionally, two crops (sorghum and pearl millet) and the wild grass $S$. verticillata were reported for the first time among the virus host range. Surprisingly, none of the 23 rice cultivars was found susceptible to IYMV, whatever the rice species. IYMV and Rice yellow mottle virus (also a sobemovirus) occur in the same geographical areas and even in the same rice fields, but on distinct hosts. Therefore, our results suggested that either rice is not a host for IYMV or very specific virus isolates are needed for positive interactions with rice. Altogether, IYMV exhibited a narrow host range, a feature commonly found with sobemoviruses [12]. According to Sõmera and Truve [13], Rottboellia yellow mottle virus (RoMoV) is able to infect $I$. cylindrica. RoMoV has not yet been reported in Burkina Faso but as both RoMoV and IYMV are present in West Africa, mixed infections in I. cylindrica or other common hosts such as maize and $R$. exaltata may occur [14]. No evidence of such mixed infections was found in this study and further investigation will be needed.

Contrary to maize, natural infection of sorghum and pear millet by IYMV has not been reported yet. However, in having three major cereal crops within its 
host range, IYMV must be considered as a highly potential threat for agricultural production where it occurs. The typical mottle symptoms observed in inoculated sorghum and pearl millet plants will be useful in assessing naturally-infected plants.

Whatever the crop, some cultivars were not infected upon virus inoculation. Possibly, those cultivars harbor useful resistance genes and could be directly used in disease management. They may also serve as sources of resistance in breeding programs to develop virus resistant varieties.

Isolate T2 exhibited reduced infection capability especially in maize. Therefore the use of individual virus isolate for studying IYMV interactions with host species clearly indicated pathogenic discrepancies compared to the composite virus isolate. These results suggested that non-infected crop cultivars found in the study may be susceptible to IYMV if adequate isolates are used. Moreover, using as many as possible virus isolates to prepare the composite virus inoculum may prove more efficient in host range studies or screening for virus resistance [15].

\section{Conclusion}

This study on the host range of IYMV shed more light on the epidemiology of Imperata yellow mottle disease. The clear expression of mottle symptoms on identified host plants, i.e. crop species (maize, sorghum and pearl millet) and wild grass species ( $S$. verticillata and $R$. exaltata) is of great importance for virus surveys in the field. This is also supported by the fact that virus infection was always characterized by symptom development. Because, most cultivars of cereal crops identified as hosts for IYMV are currently grown by farmers, virus incidence in the field as well as its impacts of yield losses are yet to be determined. The specific virus-host interactions between isolate T2 and maize cv. FBC6 underlines the need for a more thorough investigation of the virus diversity.

\section{Acknowledgements}

Financial supports for this study were provided in part by PROVEG program (Proveg: a network on plant protection through Program to support networkbased research in Africa, PARRAF http://proveg.org/accueil) and by the International Foundation for Science (IFS) through fellowship $\mathrm{N}^{\circ}$ C/5358-1 to Moustapha KOALA.

We thank Dr. Sanou Jacob, Dr. Dao Abdallah, Drabo Inoussa and Nikiema Zara for providing the seeds cereal crop cultivars.

\section{References}

[1] Aluko Olubunmi, A., Chikoye, D. and Smith Muftau, A.K. (2012) Effect of Soybean (Glycine max) Leaf Extracts on Germination and Early Growth of Speargrass (Imperata cylindrica (L.) Reauschel. African Journal of Plant Science, 6, 57-61.

[2] Walter, R. and Rao, B.K.R. (2015) Biochars Influence Sweet-Potato Yield and Nutrient Uptake in Tropical Papua New Guinea. Journal of Plant Nutrition and Soil 
Science, 178, 393-400. https://doi.org/10.1002/jpln.201400405

[3] Dozier, H., Gaffney, J.F., Mcdonald, S.K., Johnson, E.R.R.L. and Shilling, D.G. (2014) Weed Science Society of America Cogongrass in the United States: History, Ecology, Impacts, and Management. Weed Technology, 12, 737-743.

[4] Ntume, R. and Anywar, G. (2015) Ethnopharmacological Survey of Medicinal Plants Used in the Treatment of Snakebites in Central Uganda. Current Life Sciences, 1, 6-14.

[5] Mak-Mensah, E.E., Komlaga, G. and Terlabi, E.O. (2010) Antiypertensive Action of Ethanolic Extract of Imperata cylindrica Leaves in Animal Models. Journal of Medicinal Plants Research, 4, 1486-1491.

[6] Tsobou, R., Mapongmetsem, P.M. and Van Damme, P. (2013) Medicinal Plants Used against Typhoid Fever in Bamboutos Division, Western Cameroon. Ethnobotany Research \& Applications, 11, 163-174.

[7] Dat, D.D., Ham, N.N., Khac, D.H., Lam, N.T., Son, P.T., Dau, N.V., Grabe, M., Johansson, R., Lindgren, G. and Stjernstrôm, N.E. (1992) Studies on the Individual and Combined Diuretic Effects of Four Vietnamese Traditional Herbal Remedies (Zea mays, Imperata cylindrica, Plantago major and Orthosiphon stamineus). Journal of Ethnopharmacology, 36, 225-231.

[8] Kuete, V., Sandjo, L.P., Wiench, B. and Efferth, T. (2013) Cytotoxicity and Modes of Action of Four Cameroonian Dietary Spices Ethno-Medically Used to Treat Cancers: Echinops giganteus, Xylopia aethiopica, Imperata cylindrica and Piper capense. Journal of Ethnopharmacology, 149, 245-253.

[9] Kaboré, I. (2002) Etiologie de Panachure Jaune Du Chiendent (Imperata cylindrica). In: Memoire D'ingenieur Agronome, Université Polytechnique de Bobo-Dioulasso, $49 \mathrm{p}$.

[10] Sérémé, D., Lacombe, S., Konaté, M., Pinel-Galzi, A., Traoré, V.S.E., Hébrard, E., Traoré, O., Brugidou, C., Fargette, D. and Konaté, G. (2008) Biological and Molecular Characterization of a Putative New Sobemovirus Infecting Imperata cylindrica and Maize in Africa. Archives of Virology, 153, 1813-1820.

https://doi.org/10.1007/s00705-008-0190-y

[11] Sérémé, D., Ouedraogo, I., Koala, M., Konaté, M. and Gnissa, K. (2016) Development of Elisa and rt-pcr Assays for Rapid and Sensitive Detection of Imperata Yellow Mottle Virus Infecting Maize in Burkina Faso. International Journal of Current Advanced Research, 5, 1535-1540.

[12] Sõmera, M., Sarmiento, C. and Truve, E. (2015) Overview on Sobemoviruses and a Proposal for the Creation of the Family Sobemoviridae. Viruses, 7, 3076-3115.

[13] Sõmera, M. and Truve, E. (2015) Rottboellia Yellow Mottle Virus Is a Distinct Species within the Genus Sobemovirus. Archives of Virology, 160, 857-863. https://doi.org/10.1007/s00705-015-2336-Z

[14] Thottapilly, G., Van Lent, J.W.M., Rossel, H.W. and Seghal, O.P. (1992) Rottboellia Yellow Mottle Virus, a New Sobemovirus Affecting Rottboellia cochinchinensis (Itch Grass) in Nigeria. Annals of Applied Biology, 120, 405-415. https://doi.org/10.1111/j.1744-7348.1992.tb04900.x

[15] Traore, V.S.E., Asante, M.D., Gracen, V.E., Offei, S.K. and Traore, O. (2015) Screening of Rice Accessions For Resistance to Rice Yellow Mottle Virus. American Journal of Experimental Agriculture, 9, 1-12. https://doi.org/10.9734/AJEA/2015/19897 
Submit or recommend next manuscript to SCIRP and we will provide best service for you:

Accepting pre-submission inquiries through Email, Facebook, LinkedIn, Twitter, etc. A wide selection of journals (inclusive of 9 subjects, more than 200 journals)

Providing 24-hour high-quality service

User-friendly online submission system

Fair and swift peer-review system

Efficient typesetting and proofreading procedure

Display of the result of downloads and visits, as well as the number of cited articles Maximum dissemination of your research work

Submit your manuscript at: http://papersubmission.scirp.org/

Or contact as@scirp.org 